\title{
Role of Wild Suids in the Epidemiology of African Swine Fever
}

\author{
Ferran Jori, ${ }^{1,2}$ and Armanda D. S. Bastos ${ }^{2,3}$ \\ ${ }^{1}$ Integrated Animal Risk Management Unit (AGIRs), French Agricultural Research Center for International Development (CIRAD), Department of \\ Production Animal Studies, Faculty of Veterinary Science, University of Pretoria, Onderstepoort 0110, South Africa \\ ${ }^{2}$ Mammal Research Institute, Department of Zoology and Entomology, University of Pretoria, Pretoria 0002, South Africa \\ ${ }^{3}$ Biotechnology and Molecular Virology Laboratory, Department of Biological Sciences, University of Cyprus, Nicosia, Cyprus
}

\begin{abstract}
There is presently no vaccine to combat African swine fever (ASF), a viral hemorrhagic fever of domestic pigs that causes up to $100 \%$ morbidity and mortality in naive, commercial pig populations. In its endemic setting, ASF virus cycles between asymptomatic warthogs and soft ticks, with persistence in exotic locations being ascribed to the almost global distribution of susceptible soft tick and suid hosts. An understanding of the role played by diverse hosts in the epidemiology of this multi-host disease is crucial for effective disease control. Unlike the intensively studied Ornithodoros tick vector, the role of many wild suids remains obscure, despite growing recognition for suid-exclusive virus cycling, without the agency of the argasid tick, at some localities. Because the four wild suid genera, Phacochoerus, Potamochoerus, Hylochoerus, and Sus differ from each other in taxonomy, distribution, ecology, reservoir host potential, virus shedding, ASF symptomology, and domestic-pig contact potential, their role in disease epidemiology is also varied. This first consolidated summary of ASF epidemiology in relation to wild suids summarizes current knowledge and identifies information gaps and future research priorities crucial for formulating effective disease control strategies.
\end{abstract}

Key words: African swine fever, wild suids, epidemiology, ecology, Potamochoerus, Phacochoerus

\section{INTRODUCTION}

African swine fever (ASF) is a severe disease of pigs that affects all members of the family Suidae. The common warthog Phacochoerus africanus, a wild African suid, is considered the original vertebrate host of ASF virus (ASFV) which together with Ornithodoros porcinus, the soft tick vector, constitutes the ancient sylvatic virus cycle (Penrith et al., 2004a). Two additional virus cycles are recognized to

Correspondence to: Armanda D. S. Bastos, e-mail: ADBastos@zoology.up.ac.za occur in the endemic African setting, namely a domestic pig-tick cycle in which warthogs play no apparent role, and a cycle in which the virus appears capable of persisting in domestic pigs without the agency of either traditional vertebrate or invertebrate sylvatic host (reviewed by Penrith et al., 2004a). It is this latter, more recently recognized cycle that is of particular importance, as it signals the need for a paradigm shift in relation to the role played by Sus scrofa (wild and domestic) in the epidemiology of ASF, as well as a reassessment of all other susceptible wild suids. While all wild pigs are often without distinction, believed to be vertebrate virus reservoirs, several species and subspecies of Suiformes have variable roles in the epidemiology of ASF, dependant on taxonomy, geographical location, and po- 
tential contacts with domestic pigs. Literature on wild pigs and AFS is however dispersed and scattered, and information sources amalgamating the epidemiological role of different species are presently lacking. In contrast, virus pathogenesis in the Ornithodoros tick has been extensively studied (reviewed by Kleiboeker and Scoles, 2001), as has the viral genome (reviewed by Viñuela, 1985) and genetic basis of virus virulence (reviewed by Tulman et al., 2009). Variation in clinical disease and virus genome length and composition is known to occur, with infections in domestic swine ranging from sub-clinical to lethal and field strains having genomes up to $20 \mathrm{kbp}$ longer than laboratoryadapted strains (Tulman et al., 2009). Recent molecular epidemiological studies have also uncovered substantial field heterogeneity with at least 22 genotypes being identified to date on the basis of C-terminus $p 72$ gene sequencing (Bastos et al., 2003; Lubisi et al., 2005; Boshoff et al., 2007). The recent incursion of ASF into Georgia (Beltran Alcrudo et al., 2008; Rowlands et al., 2008) has highlighted the potential of the virus to expand its range towards Asia through the Caucasus and the Indian Ocean (Costard et al., 2009) as it encounters new populations of wild and domestic pigs, yet important gaps in our knowledge remain regarding the role of many wild Suidae in the maintenance of ASFV. The present paper summarizes current knowledge on the role of different species in the epidemiology of the disease and identifies priorities for research aimed at elucidating the role played by wild suid hosts and at directing future disease control strategies.

\section{Genus Phacochoerus}

\section{Taxonomy and Distribution}

Among all wild pigs in the world, warthogs of the genus Phacochoerus are considered the most significant vertebrate hosts playing a role in the maintenance of ASF (Plowright, 1977). They are the most widespread of the three African wild suid genera occurring in temperate regions throughout Africa (Fig. 1). The common warthog, Phacocheorus africanus, is the species associated with the soft tick vector and with ASF, and should not be confused with the desert warthog, P. aethiopicus, which is confined to a small area in the Horn of Africa (d'Huart and Grubb, 2001), and whose species designation was used to denote the ASF-associated common warthog prior to taxonomic revision of the genus in 2001 (d'Huart and Grubb, 2001).

\section{Ecology and Ethology}

Phacochoerus africanus are strictly diurnal, spending the night in disused aardvark (Orycteropus afer) dens or in caves and culverts (Cumming, 2005). Sounders typically number 5 or less individuals, but up to 16 individuals can be present during farrowing season. Burrow occupation is on a "first come, first served" basis (Estes, 2008), and burrow availability, together with water and food, are the major elements influencing home range and population density which range from 0.5 to $3.5 \mathrm{~km}^{2}$ and from 1 to 35 individuals per $\mathrm{km}^{2}$, respectively.

Warthog are seasonal breeders in southern Africa. Females come into oestrus in May and give birth to litters averaging three piglets in November/December (Cumming, 2005). Piglets remain in the burrow for 6-7 weeks, and weaning takes place between 2 and 6 months of age. In equatorial regions, breeding is not limited to particular months. Unlike other species of wild pigs, interbreeding with domestic pigs has not been reported.

\section{Warthog/Tick Cycle}

ASF is maintained in Africa by an ancient cycle of infection between warthogs and soft ticks of the genus Ornithodoros, from which it is unlikely to be eliminated. The taxonomy of the vector, like that of the warthog, is fraught with inconsistencies (Kleiboeker and Scoles, 2001; Bastos et al., 2009) with O. moubata and O. moubata porcinus frequently being used to denote the sylvatic tick in ASF literature, rather than $O$. porcinus, the species described by Walton (Walton, 1962, 1979) to be the warthog-associated ASF vector.

ASFV infection rates are high (generally $>80 \%$ ) in most warthog populations examined in East and southern Africa, however, notable differences in ASF seroprevalence in neighboring warthog populations have been recorded. In the Serengeti region of Tanzania, for example, ASF antibody prevalence in warthogs was $100 \%$, while in Magadi it was 50\% (Heuschele and Coggins, 1969). Similarly, in South Africa, ASF seroprevalence was $90 \%$ in the Kruger National Park and only 4\% in nearby localities (Pini and Hurter, 1975; Plowright et al., 1994). An age-related trend in ASF seroprevalence has also been reported. In the Queen Elizabeth National Park, Uganda, ASF seroprevalence was $58 \%$ in warthogs in the $4-12$-month-old age category, but decreased to an average of $8 \%$ after 24 months of age (Plowright, 1981; Plowright et al., 1994). 


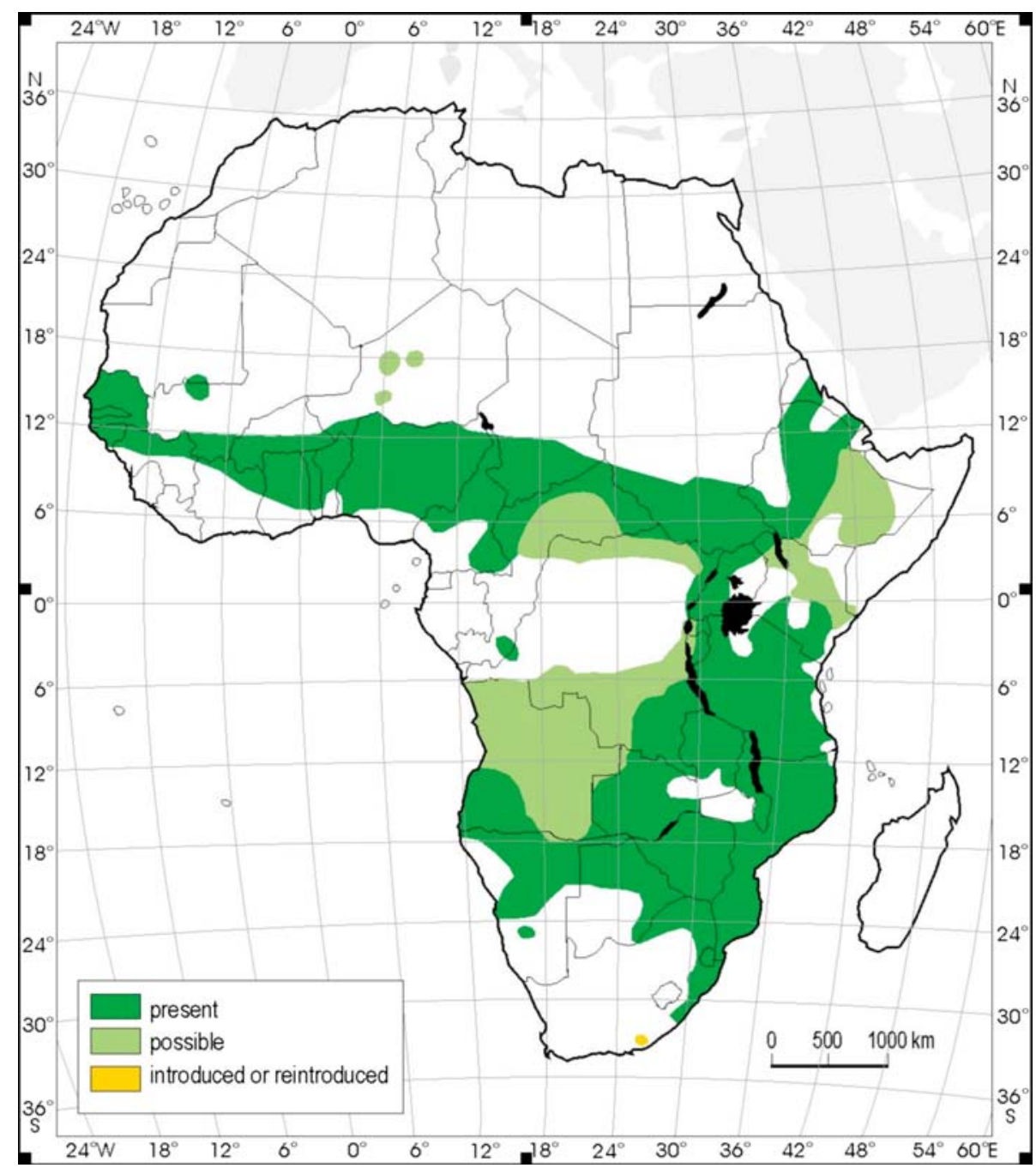

Figure 1. Distribution of the common warthog (Phacochoerus africanus).
Infected warthogs show no signs of disease, but considerable viral replication and viremia occurs in young animals (Thomson et al., 1980). Infection of neonate warthogs occurs in burrows containing infected argasid ticks and is characterized by detectable viremia for up to 11 days, becoming undetectable in blood after 33 days. After a generalized phase of infection, the virus localizes in various superficial lymph nodes, with virus levels of up to $10^{6,6} \mathrm{HAD}_{50} / \mathrm{ml}$ occurring at lymphatic sites (Plowright et al., 1994). The virus has a predilection for lymph nodes of the head (Plowright, 1981), and animals remain infected for life (Wilkinson, 1989). While viremias have been detected in young animals, there is, to date, no evidence for subsequent viremias in older animals (Thomson, 1985).

Blood virus levels of at least $10^{3}-10^{4} \mathrm{HAD}_{50} / \mathrm{ml}$ that are necessary to infect ticks, are only achieved in young suckling warthogs with limited immunity (Heuschele and Coggins, 1969; Plowright, 1977). As circulating virus levels of adult warthogs rarely exceed $10^{2} \mathrm{HAD}_{50} / \mathrm{ml}$, they are unable to infect ticks. Instead, it is the neonate warthogs, that on becoming infected when bitten by resident ASFVpositive Ornithodoros in the burrow, develop a transient viremia lasting 2-3 weeks which is sufficient to infect naive ticks feeding on them (Thomson, 1985), that appear to play a crucial role in maintaining and amplifying virus in the sylvatic cycle. As warthog farrowing is seasonal, infection of naive warthogs and ticks is also presumed to be cyclical in southern Africa.

Transmission of the virus sexually, trans-ovarially and trans-stadially in Ornithodoros (reviewed by Kleiboeker and Scoles, 2001), facilitates maintenance of the virus in colonies for periods of up to 15 months (Plowright et al., 1970), in the absence of an infectious vertebrate blood meal. While it has been suggested that they may even be capable of maintaining the virus indefinitely (Plowright, 1977), definitive estimates of the upper time limit of virus 
clearance from tick colonies are lacking and it remains unclear to what extent virus transmission and survival may be facilitated by soft ticks alone. In the absence of evidence for horizontal or vertical transmission in warthog, maintenance of the virus is believed to be dependent on warthog burrow-dwelling Ornithodoros porcinus (Pierce, 1974; Penrith et al., 2004a). However, ASF seroprevalence of close to $100 \%$ in warthogs from areas in central Kenya, has been observed in the absence of argasid ticks, suggesting that an alternative form of virus maintenance may occur there (Pierce, 1974). The vast majority of studies in other regions of eastern and southern Africa have, however, confirmed the existence of a warthog- tick cycle corresponding to the distributional range of warthogs and to the historical ASF outbreaks, which originally implicated the warthog as the vertebrate wildlife species of greatest significance in ASF epidemiology in Africa (Plowright, 1981). The existence of this sylvatic cycle has been described in numerous countries (Table 1), however a similar host-tick relationship between the desert warthog P. aethiopicus and Ornithodoros ticks in the Somali ecosystem, while suspected (Penrith et al., 2004a), has not been documented to date.

Infestation rates of warthog burrows in areas where argasid ticks are present are variable in terms of the numbers and stages of ticks found, the AFSV infection rate and proportion of burrows infested (Plowright et al., 1969; Bastos et al., 2009). Reasons for this variation remain unclear, but variable warthog density and activity in burrows, together with virus heterogeneity are likely contributing factors. The latter is supported by the observation that variation in establishing a generalized infection in ticks, which is crucial for efficient transmission of the virus during feeding, occurs when using different virus strains, and that the timing of virus-induced mortality in female ticks is variable between studies (reviewed by Kleiboeker and Scoles, 2001). Furthermore, there are indications that host variation may be important as ticks originating from different geographical localities, displayed locality-specific differences in infection rates, despite being infected with the same virus strain (Kleiboeker and Scoles, 2001).

In West Africa, the existence of a tick-warthog cycle has not been demonstrated, except for a single record of Ornithodoros in a warthog burrow in Sierra Leone (Penrith et al., 2004a). Absence of $O$. porcinus in Senegal and Cameroon (Vial et al., 2007) may explain why circulation of the virus has not been demonstrated in warthogs outside of East and southern Africa, thus far (Jori et al., 2007). While other soft ticks such as O. sonrai in Senegal (Vial et al., 2006), have been identified as being potential vectors of ASFV (Vial et al., 2007), there are, to date, no reports of this tick species in warthog burrows (Jori et al., 2007). It is therefore unlikely that ASFV circulates among warthogs populations in West Africa (Taylor et al., 1977). Taken together, these data indicate that the joint presence of warthogs and Ornithodoros ticks does not necessarily imply the existence of an ASFV tick-host cycle, as warthogs in some regions can be free of infection even in the presence of Ornithodoros ticks (Pini and Hurter, 1975; Arnot et al., 2009). Similarly, warthogs occurring in areas free of ticks are not necessarily free of ASFV (Pierce, 1974). Care should therefore be exercised in extrapolating the presence of an ASF sylvatic cycle to all areas of the African continent where the sylvatic host genera co-occur.

\section{Routes of Transmission}

Direct transmission from infected warthogs to other warthogs or to domestic pigs has repeatedly failed (Plowright, 1981), and is only suggested from a single report (De Tray, 1959). Experimental infection revealed that lymphatic tissues of infected warthogs contain lower quantities of virus (ranging from $10^{2,9} \mathrm{HAD}_{50}$ to $10^{8}$ $\mathrm{HAD}_{50}$ ) than those found in infected domestic pigs (see Table 2). Transmission between warthogs, and from warthogs to pigs, occurs indirectly via argasid ticks and most likely when pigs sharing grazing areas with warthogs are bitten by infected soft ticks. The hypothesis that domestic pigs can become infected by ingestion of infected warthog tissues is not supported by experimental data (Penrith et al., 2004a). It is more likely that pigs become infected after being bitten by soft ticks, brought to human settlements with warthog carcasses or by ingestion of infected ticks. Since argasid ticks have on occasion been found on warthogs outside their burrows (Horak et al., 1983; Hamblin et al., 1990), and Ornithodoros ticks have been observed in intestinal contents of warthog (Thomson, 1985), both interspecies transmission routes are plausible.

\section{Control}

The physical separation of domestic pigs and wildlife has provided good results in controlling the disease, even in areas where the disease is known to circulate among natural populations of infected warthogs, and forms the basis of ASF disease control regulations in many countries where the disease is endemic (Penrith et al., 2004a). 
Table 1. Countries in which ASF has been Detected in Wild Pig Species

\begin{tabular}{|c|c|c|c|}
\hline Country & Species of wild pig & $\begin{array}{l}\text { Reported } \\
\text { involvement }^{\mathrm{a}}\end{array}$ & References \\
\hline South Africa & $\begin{array}{l}\text { Warthog } \\
\text { Bushpig } \\
\text { Feral pig }\end{array}$ & $\begin{array}{l}\text { Yes } \\
\text { Yes } \\
\text { No }\end{array}$ & $\begin{array}{l}\text { Pini and Hurter (1975), Thomson et al. (1980), } \\
\text { Thomson (1985) }\end{array}$ \\
\hline Zimbabwe & $\begin{array}{l}\text { Warthog } \\
\text { Bushpig }\end{array}$ & $\begin{array}{l}\text { Yes } \\
\text { Yes }\end{array}$ & Thomson (1985), Anderson et al. (1998), Penrith et al. (2004a) \\
\hline Zambia & Warthog & Yes & Wilkinson (1988) \\
\hline Malawi & $\begin{array}{l}\text { Warthog } \\
\text { Bushpig }\end{array}$ & $\begin{array}{l}\text { Yes } \\
\text { No }\end{array}$ & Haresnape and Mamu (1986), Haresnape et al. (1988) \\
\hline Mozambique & Warthog & Yes & Penrith et al. (2007) \\
\hline Botswana & $\begin{array}{l}\text { Warthog } \\
\text { Bushpig }\end{array}$ & $\begin{array}{l}\text { Yes } \\
\text { No }\end{array}$ & Thomson (1985), Plowright et al. (1994) \\
\hline Namibia & $\begin{array}{l}\text { Warthog } \\
\text { Bushpig }\end{array}$ & $\begin{array}{l}\text { Yes } \\
\text { No }\end{array}$ & Thomson (1985), Plowright et al. (1994) \\
\hline Kenya & $\begin{array}{l}\text { Warthog } \\
\text { Bushpig } \\
\text { Giant Forest hog }\end{array}$ & $\begin{array}{l}\text { Yes } \\
\text { Yes } \\
\text { Yes }\end{array}$ & Montgomery (1921), De Tray (1959), De Tray (1963) \\
\hline Tanzania & $\begin{array}{l}\text { Warthog } \\
\text { Bushpig } \\
\text { Giant Forest hog }\end{array}$ & $\begin{array}{l}\text { Yes } \\
\text { No } \\
\text { No }\end{array}$ & Plowright (1977), Thomson (1985), Plowright et al. (1994) \\
\hline Uganda & $\begin{array}{l}\text { Warthog } \\
\text { Bushpig } \\
\text { Giant Forest hog }\end{array}$ & $\begin{array}{l}\text { Yes } \\
\text { No } \\
\text { No }\end{array}$ & Plowright (1977), Thomson (1985), Plowright et al. (1994) \\
\hline DRC & $\begin{array}{l}\text { Bushpig } \\
\text { Giant Forest hog }\end{array}$ & $\begin{array}{l}\text { Yes } \\
\text { No }\end{array}$ & [Mulumba, 2007, personal communication] \\
\hline Senegal & $\begin{array}{l}\text { Warthog } \\
\text { Bushpig }\end{array}$ & $\begin{array}{l}\text { No } \\
\text { No }\end{array}$ & Jori et al. (2007), Vial et al. (2007) \\
\hline Nigeria & $\begin{array}{l}\text { Warthog } \\
\text { Bushpig }\end{array}$ & $\begin{array}{l}\text { No } \\
\text { Yes }\end{array}$ & Taylor et al. (1977), Luther et al. (2007) \\
\hline Cameroon & $\begin{array}{l}\text { Warthog } \\
\text { Bushpig } \\
\text { Giant Forest hog }\end{array}$ & $\begin{array}{l}\text { No } \\
\text { No } \\
\text { No }\end{array}$ & Thomson (1985) \\
\hline Benin & $\begin{array}{l}\text { Warthog } \\
\text { Bushpig }\end{array}$ & $\begin{array}{l}\text { No } \\
\text { No }\end{array}$ & Thomson (1985) \\
\hline Spain & Wild boar & Yes & Perez et al. (1998), Arias and Sanchez-Vizcaino (2002) \\
\hline Portugal & Wild boar & Yes & Louza et al. (1989) \\
\hline Italy (Sardinia) & Wild boar & Yes & Laddomada et al. (1994), Mannelli et al. (1998) \\
\hline Mauritius & Feral pig & Yes & [Jori, personal observation] \\
\hline Madagascar & Bushpig & No & Roger et al. (2001) \\
\hline Cuba & Feral pig & Yes & Siméon-Negrin and Frias-Lepoureau (2002) \\
\hline Azerbaijan & Wild boar & No & Beltran Alcrudo et al. (2008) \\
\hline Georgia & Wild boar & No & Beltran Alcrudo et al. (2008) \\
\hline Russia & Wild boar & Yes & Beltran Alcrudo et al. (2008) \\
\hline
\end{tabular}

DRC Democratic Republic of Congo.

${ }^{a}$ Confirmed by laboratory diagnosis.

${ }^{\mathrm{b}}$ Imported for hunting purposes. 


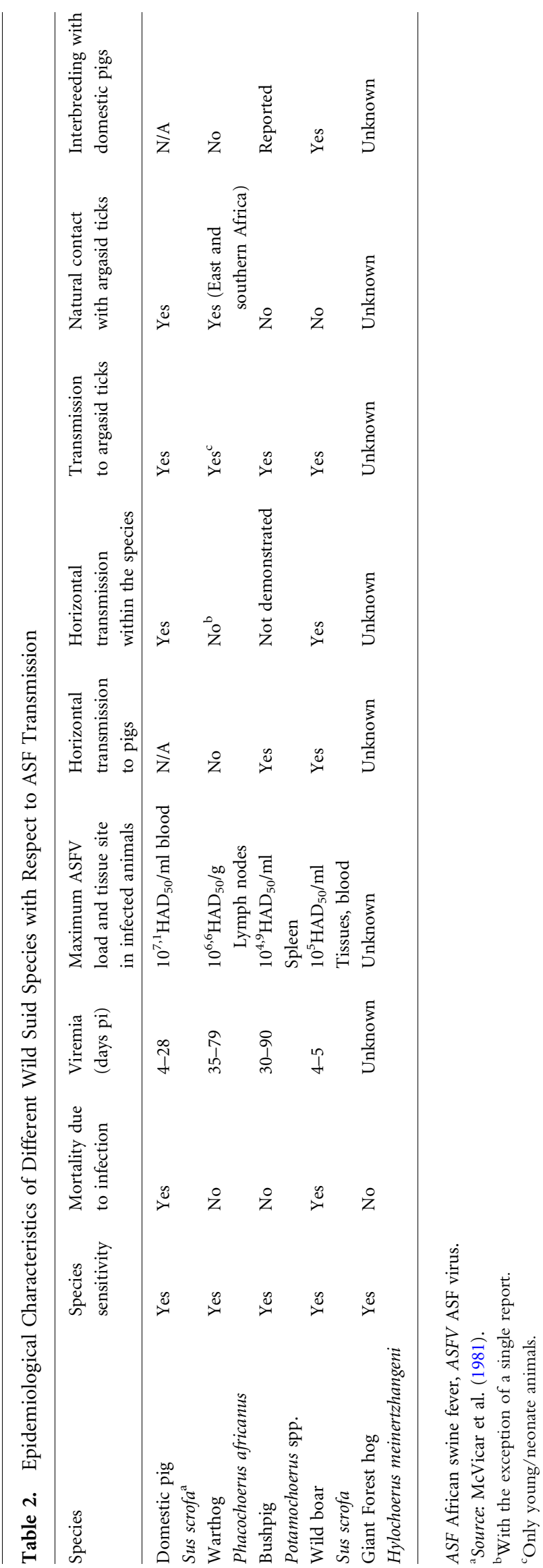

\section{Genus Potamochoerus}

\section{Taxonomy and Distribution}

The bushpig, Potamochoerus larvatus, and Red River hog, $P$. porcus, are the two representatives of the African genus Potamochoerus. Both species are of medium body size, with an elongated snout and a long, often brightly colored coat. $P$. porcus is brighter in color than the bushpig, with a distinct white dorsal stripe and crest, long white whiskers and eartufts, occurring only in West and Central Africa (Fig. 2). Evident contraction in the west and extreme north of its range has occurred, due to human activity, overhunting, and habitat encroachment (Vercammen et al., 1993). The bushpig (Potamochoerus larvatus) is darker in coat color, often without the distinct white masks and long eartufts characteristic of $P$. porcus, and has a relatively wide range (Fig. 3). In Madagascar, $P$. larvatus is considered an invasive species suspected of having been introduced more than 2000 years ago, although the exact origin and date of their arrival remains unknown (Roger et al., 2001). Although two morphological variants are suspected (Vercammen et al., 1993), data on distribution are sketchy and imprecise. Genetic studies on Potamochoerus are lacking and would be useful for clarifying the systematic and distributional limits of all members and variants of this species.

\section{Ecology and Ethology}

Very few field studies have been conducted, with the exception of P. larvatus in southern Africa (Seydack, 1990; Vercammen et al., 1993). The distribution of both species appears to be limited by the continuous availability of food, water, and cover, and they are only rarely reported in open woodland, savannah, or other more arid and open habitats (Seydack, 1990). Both species live in small family groups usually comprising 4-10 individuals. However, in equatorial regions, groups of more than 30 individuals were reported for the Red River hog (White, 1994). They are usually sedentary, territorial, and predominantly nocturnal, although diurnal activity occurs in cooler months. During periods of inactivity, they shelter in dense vegetation, and they may construct bad weather nests during cold and wet spells. Average daily movement distances for bushpigs were found to be $3 \mathrm{~km}$, ranging between 0.5 and $5.8 \mathrm{~km}$ in western South Africa (Seydack, 1990). Density of Potamochoerus spp. in different parts of South Africa ranges from 0.35 to 0.5 individuals $/ \mathrm{km}^{2}$ but can go up to 3 individuals $/ \mathrm{km}^{2}$ in tropical forest regions. 


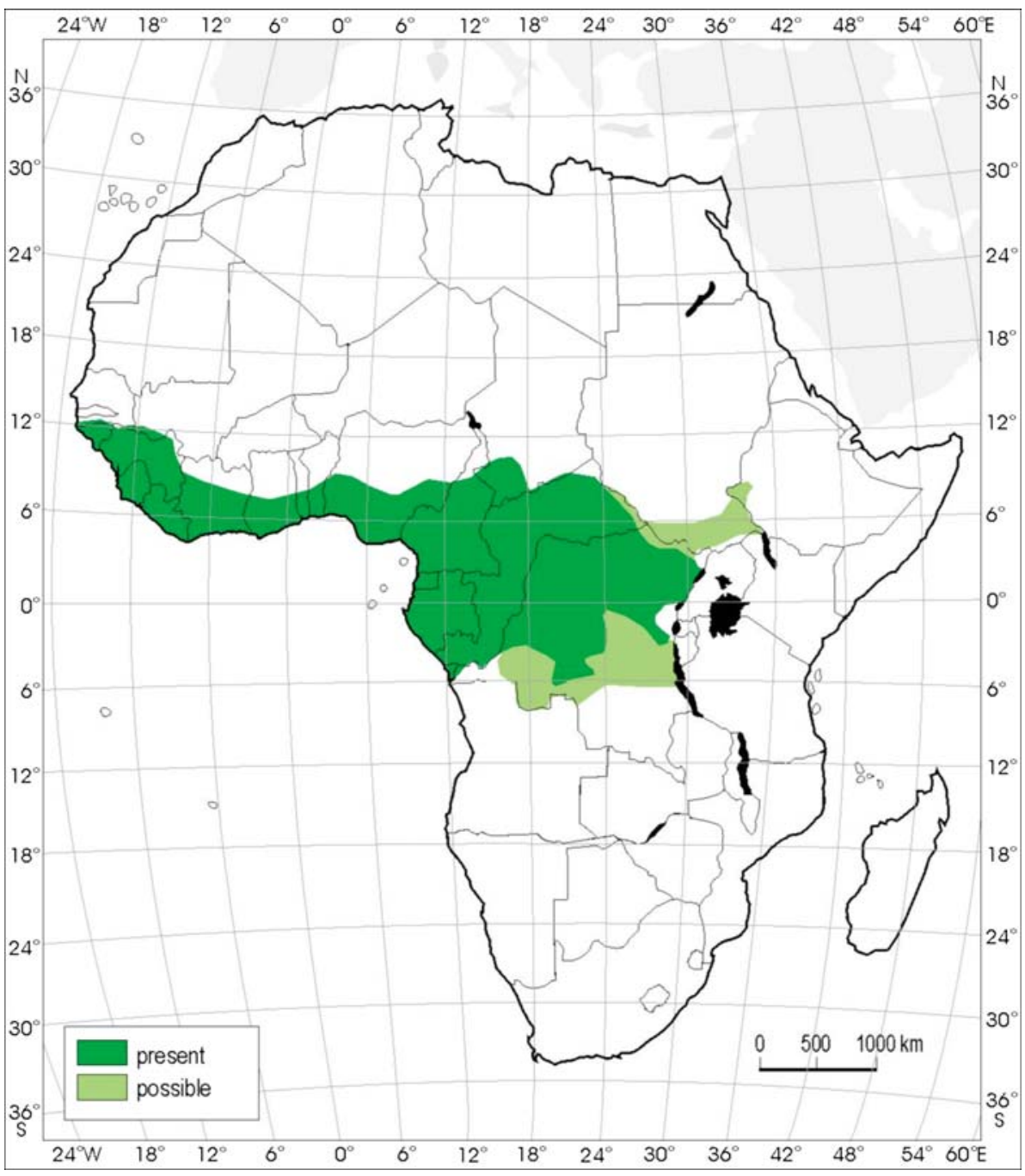

Figure 2. Distribution of the Red River hog (Potamochoerus porcus).
A distinctive aspect of Potamochoerus spp., compared to other wild African pigs, is its suspected hybridization with domestic pigs and wild boars (Sus scrofa). This phenomenon, which has been reported in different parts of Africa (Vercammen et al., 1993; Kingdon, 2003) and Madagascar [Jori, personal observation], invariably describes free-ranging female pigs being mounted by male Potamochoerus. In the absence of scientific confirmation of intergeneric hybridization, the suspected existence of Potamochoerus spp. $\times$ domestic pigs remains anecdotal, but significant as the asymptomatic carrier status of Potamocheorus, and implies that hybrids, should they occur, could become asymptomatic carrier pigs which could maintain and disseminate the virus to more susceptible pure-bred pigs, and horizontally among themselves.

\section{Role of Potamochoerus spp. in the Epidemiology of ASF}

It is generally believed that bushpigs are less important than warthogs in the epidemiology of ASF, since they exist in lower numbers, have lower infection rates (Wilkinson, 1988), are elusive, predominantly nocturnal creatures that are unlikely to come into contact with domestic pigs, and (at least in South Africa) occur in areas outside of the ASF control area that coincides with historical pig outbreaks and warthog distribution (Thomson, 1985). Despite knowing that they are susceptible to infection, precise estimates of ASFV prevalence in diverse natural populations of bushpigs are generally lacking (Jori et al., 2007). One general estimate puts ASFV infection in bushpigs as occurring 10 times less frequently than in warthogs (Mansveld, 1963), while De Tray (1963) 


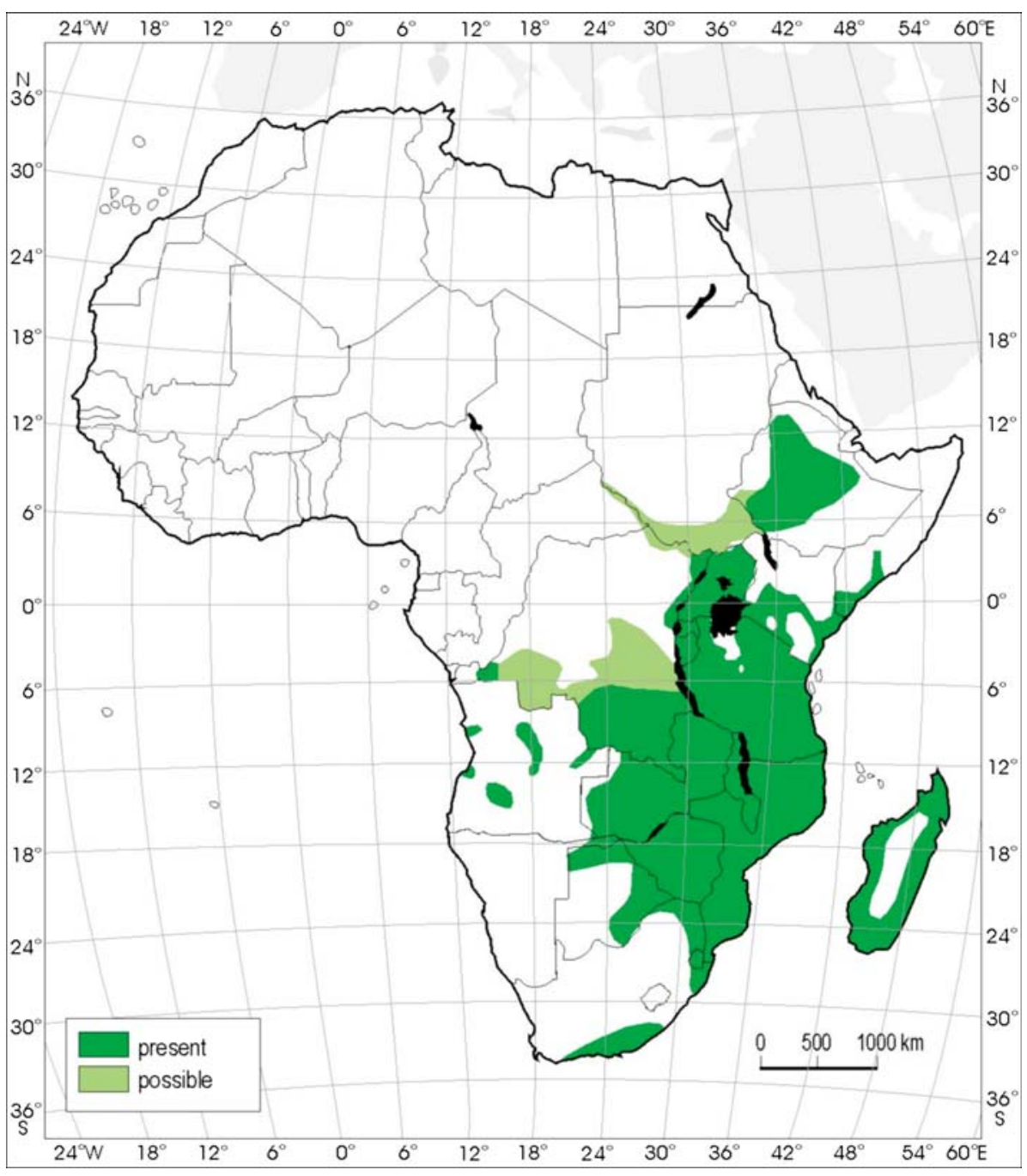

Figure 3. Distribution of the bushpig (Potamochoerus larvatus). reported "low frequencies" of the virus in 50 bushpigs from Kenya. Screening of bushpigs in Madagascar, following the introduction of the virus to this island in 1998, failed to demonstrate ASFV antibody circulation (Roger et al., 2001), as has screening at other localities (De Tray, 1963). The nocturnal, secretive habits of bushpigs, that make them difficult to capture, have no doubt contributed to the lack of reliable ASF prevalence estimates in bushpigs, however the cumulative results also suggests that ASFV probably circulates only occasionally or at very low levels in this wild suid.

\section{Asymptomatic Carrier Hosts}

The susceptibility of bushpigs to ASF was first demonstrated in 1921 in Kenya (Montgomery, 1921). A few decades later, virus was isolated from several bushpigs in the same country (De Tray, 1963) and, more recently, detected by PCR in the Red River hog in West Africa (Luther et al., 2007). Therefore, both species have been reported as being naturally infected with ASFV in East and West Africa. Surprisingly, there are very few reports of ASFV in bushpigs from southern Africa or Madagascar. Furthermore, bushpigs show no clinical signs when infected with ASF viruses that are pathogenic to domestic pigs (Anderson et al., 1998).

\section{Viremia and Pathogenesis}

Infection in bushpigs results in low levels of viral replication, minimal pathological damage and apostosis in lymphoid tissue, and low spread of the virus to other lymphoid tissues (Oura et al., 1998). Anderson and coworkers (1998) recorded that the duration of viremia in bushpigs was longer than that in warthogs, and that ASFV persisted at levels ranging between $10^{2}$ and $10^{4.9} \mathrm{HAD}_{50} / \mathrm{ml}$ (Table 2) in the lymphatic tissues for at least 34 weeks, following primary infection. Bushpigs therefore have sufficiently high levels of virus to induce infection in susceptible domestic pigs (Anderson et al., 1998). 


\section{Routes of Transmission}

Horizontal Transmission

During viremia, transmission between experimentally infected bushpigs and domestic pigs could be demonstrated, with one of the two viruses used. The highly virulent Lil20/ 1 strain of East African origin was readily transmitted, but transmission failed when bushpigs were infected with VICT90/1, a genotype I virus that groups with West African, domestic pig cycle viruses (Bastos et al., 2003), that are generally associated with sub-clinical infection. Horizontal transmission between bushpigs did not occur, irrespective of the virus strain used (Anderson et al., 1998), suggesting that this species may require higher doses of virus to become infected, or is only susceptible to particular virus variants that were not evaluated. However, as infected pigs which excrete large quantities of virus did not transmit the virus to bushpigs, it is also possible that this species is not highly susceptible to infection by direct contact. The study by Anderson and coworkers (1998) highlights the importance of virus heterogeneity when considering aspects such as interspecies transmission, duration of viremia, and susceptibility of wild suids to secondary infection with a heterologous virus, and provides a likely explanation for the variable transmission dynamics of ASF in wild suids, such as the single record of horizontal transmission between warthogs (De Tray, 1959).

\section{Tick Infection}

Experimentally infected bushpigs were able to infect Ornithodoros soft ticks, however, under natural conditions, it is not likely that bushpigs maintain a close relation with soft ticks, since this suid does not frequent burrows (Roger et al., 2001). Although this association has rarely been investigated, antibodies against salival glands of Ornithodoros could not be demonstrated in the sera of 27 bushpigs surveyed in the West coast of Madagascar (Jori et al., 2007).

Despite suspecting that bushpigs can, on some occasions, play a significant role in the epidemiology of the disease (Haresnape et al., 1985), the extent of their involvement remains unclear. Outbreaks of ASF in domestic pigs have occurred in some areas of Malawi in the presence of bushpigs, and absence of warthogs and soft ticks (Wilkinson, 1984; Haresnape et al., 1985). As bushpigs attracted by crops come close to communal lands, they could encounter dead infected pigs and possibly become infected by ingesting pig carcasses.
Equally, bushpigs, which are a favored game species, could infect domestic pigs by ingestion of ASFV particles in infected tissue (Penrith et al., 2004b).

\section{Genus Hylochoerus}

The Giant Forest hog, Hylochoerus meinertzhangeni, lives in montane forests and adjacent grasslands below $3750 \mathrm{~m} /$ 12,000 feet above sea level across Central Africa (d'Huart, 1993). There is only one record of a Giant Forest hog being infected by ASFV (Montgomery, 1921). Since the distribution of this species (Fig. 4) is restricted to areas of dense forest where domestic pig production is not common, and as domestication is precluded by high aggression, territoriality, and large home ranges, it is unlikely that they have or will play a significant role in the transmission or dissemination of ASFV.

\section{Genus Sus}

\section{Distribution and Taxonomy}

There are two wild suids of the genus Sus that are significant in ASF epidemiology, namely the wild boar and the feral pig. Both are Sus scrofa. The Eurasian wild pig has one of the widest distributions of all terrestrial mammals (Fig. 5) and its range has been greatly expanded by human agency (Oliver et al., 1993). It is the ancestor of most common domestic pigs.

The feral pig is a domestic pig that is living in the wild, either having been released or having escaped from confinement. It was introduced by colonization to many New World countries and numerous islands in the Caribbean, and Indian and Pacific Oceans; while it is difficult to distinguish from the wild boar, there are some morphological differences (Mayer and Brisbin, 1997). Hybridization between the feral pig and wild boar can occur; the hybrids are perfectly viable and almost, if not wholly, indistinguishable from purebred Eurasian wild boars (Mayer and Brisbin, 1997).

\section{Ecology and Ethology}

Wild boars occur in areas of scrub and forest throughout their distributional range. They are omnivorous and activity is concentrated from dusk to dawn. Wild boars rest in tight groups with bodily contact, and their primary resting periods are at night and during the early afternoon. 


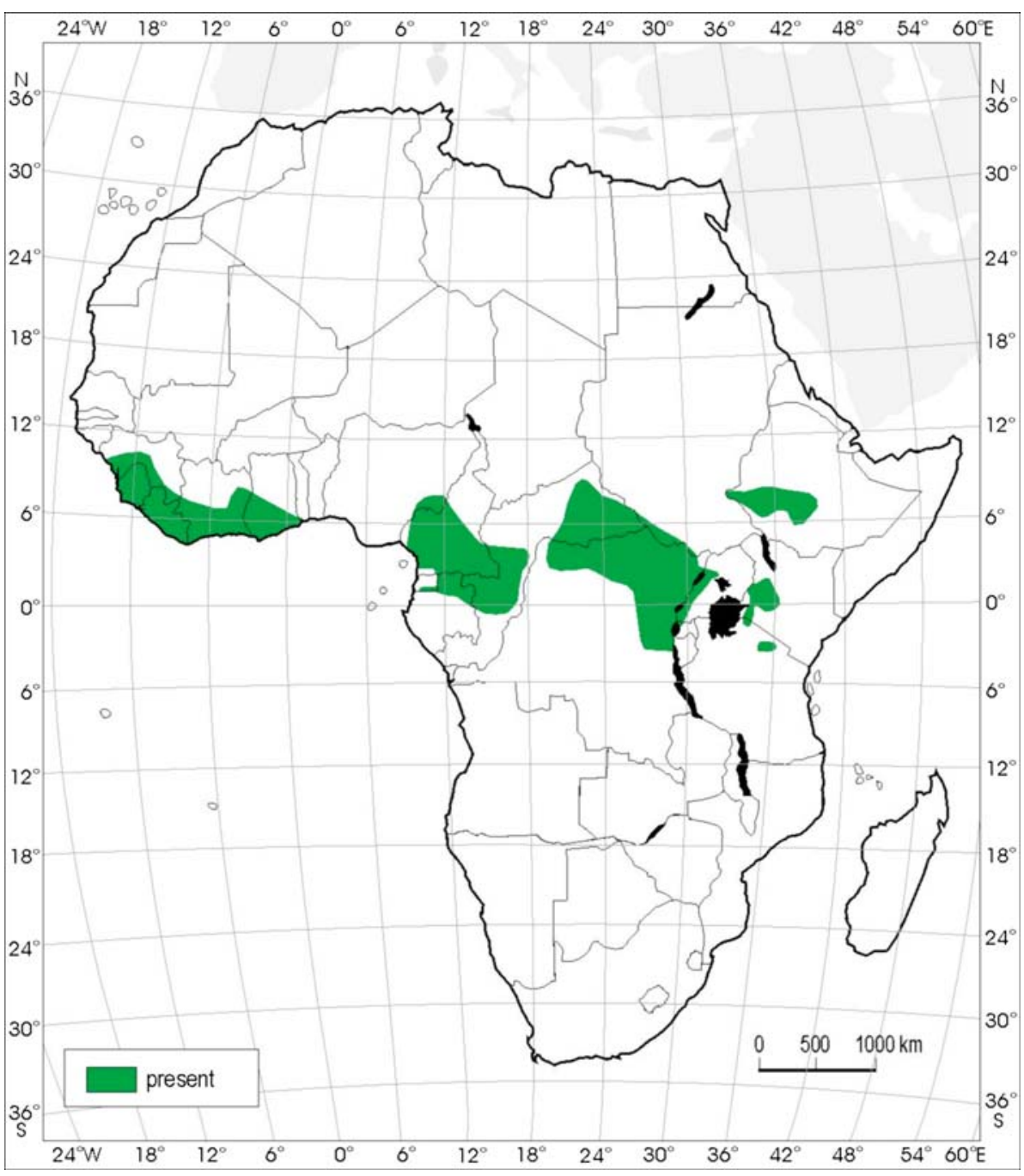

Figure 4. Distribution of the Giant Forest hog (Hylochoerus meinertzhangeni).
Sounders encompass up to 20 individuals, but can total as many as 100 animals (Oliver et al., 1993). Adult males are solitary. Farrowing season occurs in late winter or early spring, depending on regional climate. In the feral pig, domestication has enhanced ovulation rate, and feral forms are reproductive throughout the year (Mauget, 1991). Litter size varies between 4 and 12 piglets, which are weaned after 2-3 months. Sexual maturity is reached at 10 months in males and between 8 and 12 months in sows, depending on food availability (Mauget, 1991).

\section{Role of Sus scrofa in the Epidemiology of ASF}

African swine fever has been introduced in many areas where Sus scrofa is present (Table 1). This species is highly susceptible to both natural and experimental infection (McVicar et al., 1981); in the Iberian Peninsula, it perished in large numbers following initial introduction of ASFV (Wilkinson, 1989). Depending on the virulence of circulating strains, some animals survive, and positive animals have been detected during serological surveys (Perez et al. 1998). In Florida, it was observed that feral pigs were extremely susceptible to domestic pig isolates from the Dominican Republic (McVicar et al., 1981).

The role of wild Sus in the epidemiology of the disease is unclear. They excrete virus in similar quantities as domestic pigs (see Table 2). However, some authors have suggested that they are less efficient in transmitting the infection to other wild boars than is the case for domestic pigs (Laddomada et al., 1994).

In Spain, serological monitoring of wild boars during the 1990s showed seroprevalence levels lower than $0.5 \%$, suggesting that the disease was fatal in wild boars (Bech Nielsen et al., 1995). However, several years later, the number of seropositive animals increased to $10 \%$ in some areas and seropositivity levels coincided with areas where domestic pigs remained infected (Perez et al., 1998), suggesting that the initial virulent virus had become 


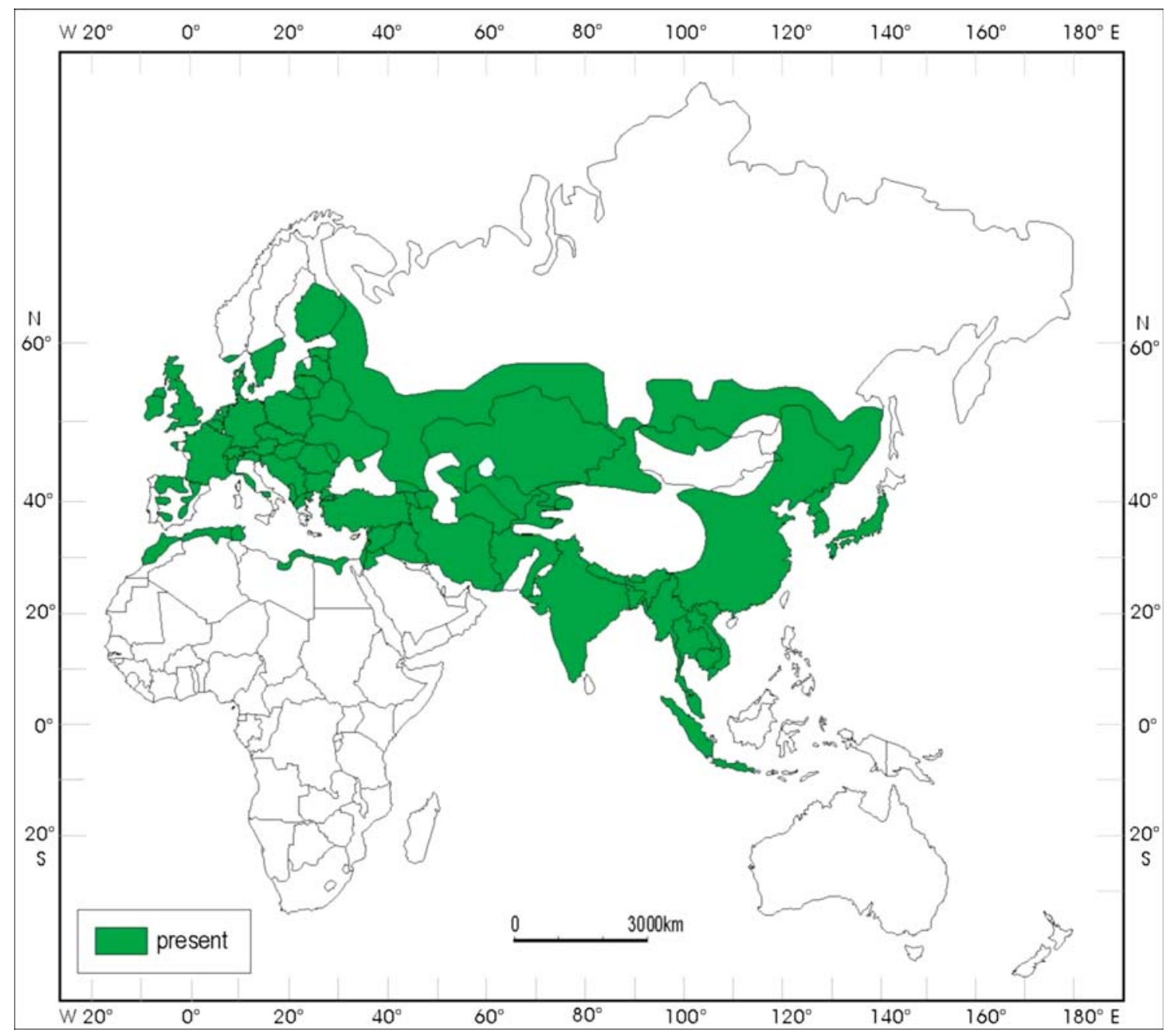

Figure 5. Distribution of Eurasian wild boar (Sus scrofa).

attenuated. This again highlights the importance of virus heterogeneity, as ASF virus expression in wild boar populations may change over time and will, together with other factors, be influenced by the virulence of circulating strains. In Sardinia and Spain, it has been observed that the virus tends to disappear from wild boar populations if there are no subsequent re-infections through contacts with freeranging infected pigs (Laddomada et al., 1994). Therefore, wild boars are considered not to play a major role as a virus reservoir in the absence of free-ranging, infected domestic pigs (Laddomada et al., 1994; Perez et al., 1998). However, in areas where the disease is actively circulating, where wild boars occur at high densities and where there are contacts with free-ranging pigs, they can represent a serious challenge as disseminators of the virus across different territories. Following the recent introduction of ASFV to Georgia in June 2007, the disease has been spreading within the country and wild boars are likely to have become infected through contact with free-ranging pigs. Wild boars have been confirmed as becoming infected in the Russian Republic of Chechnya, bordering Georgia, and are equally suspected of having spread the disease to Azerbaijan and Armenia (Beltran Alcrudo et al., 2008). While the latter has, as yet, to be confirmed by laboratory analysis [Penrith, personal communication], it is feared that the infection in the wild boar population could complicate both short- and long-term control of the disease.

The routes of transmission between domestic and wild pigs are likely to be through ingestion of infected carcasses, if animals are free-ranging, or by direct contact. Nevertheless, information regarding the way in which the virus is transmitted between wild boars or from the latter to domestic pigs is unclear.

In the case of the European wild boar, contact with infected ticks in their natural environment is unlikely since they do not have a permanent place to rest. Thus far, contact 
between soft ticks (Ornithodoros erraticus) and wild boars has not been demonstrated (Louza et al., 1989). However, this situation could exceptionally occur if they share common home ranges with domestic pigs from infested pig pens.

\section{Control}

Despite circulation of ASFV in wild boar populations in areas of the Iberian Peninsula or Sardinia, the disease can be controlled by preventing contact between domestic pigs and wild boars. The maintenance of the disease in some Mediterranean countries appears to be associated with the practice of freerange pig production, rather than with the circulation of the virus among wild boar populations, as the disease was eradicated from Cuba, despite the presence of feral pigs (SiméonNegrin and Frias-Lepoureau, 2002). In the Caucasus, proposed methods of control are separation of feral and domestic pigs, and disposal of carcasses and offal from domestic pigs and hunted wild boars, in order to prevent their consumption by free-ranging domestic or wild pigs (Beltran Alcrudo et al., 2008). Obtaining wildlife samples with the collaboration of hunter's associations has proven to be an efficient means for monitoring the disease in wild boar populations (Perez et al., 1998; Arias and Sanchez-Vizcaino, 2002).

\section{Diagnosis of ASF in Wild Suids}

The methods of ASF diagnosis in domestic pigs are equally applicable to feral swine and wild boars (Laddomada et al., 1994; Bech-Nielsen et al., 1995). Lesions found at postmortem are typical of ASF, and virus can be detected in tissues and blood. With respect to wild African suids, virus isolation (De Tray, 1963), together with PCR (Luther et al., 2007) and immunohistochemistry (Oura et al., 1998), have been the primary means of detecting the virus in bushpigs. Serology is not the method of choice for detecting ASF in bushpigs. Indeed, ASFV infection in Potamochoerus results in a diminished immune response against the virus (Oura et al., 1998), and could explain why many authors have failed to detect circulating antibodies in bushpigs (Haresnape et al., 1985; Anderson et al., 1998; Jori et al., 2007). In warthogs, virus is usually only isolated from warthog lymphatic tissue, with the exception of viremic neonate warthogs (Plowright, 1981; Thomson, 1985). Exposure to ASFV may be detected serologically (Plowright et al., 1994) using any one of a number of available tests, such as conventional indirect ELISA (Alcaraz et al., 1995), recombinant p30 protein ELISA (Perez-Filgueira et al., 2006), or Western blot (Wilkinson, 1984). It has, however, been shown that the percentage of positive warthog samples detected by recombinant and indirect ELISA can be low (Perez-Filgueira et al., 2006), and that confounding results, such as only one of three sibs being seropositive, can occur during warthog seroprevalence studies (Thomson et al., 1983). While the latter points to the possibility of nonspecific, cross-reactions and false positives, the low and zero prevalence results for other warthog populations and for diverse bushpig populations, respectively, indicate a clear need to develop serological tests specifically for wild African suids, or alternatively to validate more extensively, tests developed for domestic pigs for their utility in these hosts.

\section{CONCLUSIONS}

With the exception of warthogs in East and southern Africa, and perhaps the wild boars in Mediterranean countries, the role of wild pigs in the epidemiology of ASF has barely been investigated and many knowledge deficiencies remain. In the absence of a vaccine, it is important to fully understand the importance of all role-players in the epidemiology of the disease, including wild suids, to ensure that efficient control measures are put in place, particularly as ASFV has the potential to spread to exotic localities. In achieving this, the main research priorities identified in this review as being crucial to elucidating the role of wild suids in the epidemiology of the disease are the following:

(i) The bushpig is probably the least studied Suiform species regarding its role in the epidemiology of ASF in Africa and Madagascar, despite its confirmed role as a reservoir host of the disease. Prevalence data and further research on possible sources of infection and potential to maintain and transmit virus to domestic pigs should be addressed.

(ii) In the case of the common warthog, variation in virus circulation in warthogs at different localities should be revisited in relation to argasid ticks using new technologies, such as PCR. The literature clearly indicates that alternatives to the recognized and generally accepted warthog/soft tick sylvatic cycle may exist and warrants further investigation.

(iii) The existence of a sylvatic cycle involving desert warthogs and soft ticks in the Horn of Africa requires confirmation. 
(iv) The role of suid hybrids (e.g., pig-boar) in ASF epidemiology, and confirmation of Potamochoerus spp. $\times$ Sus scrofa hybridization deserves consideration.

(v) The dynamics of ASFV transmission within populations of feral pigs and wild boars would provide useful information regarding the role of these wild suids as reservoirs of infection, and will assist with designing more efficient methods of control in areas with substantial wild boar populations.

(vi) Finally, technological developments aimed at providing reliable and validated diagnostic screening methods for wild African suids are required to clarify the role of these vertebrate hosts in the epidemiology of the disease.

In addressing all of the previously mentioned initiatives, host and virus heterogeneity, which underpins the variable expression of ASF in wild suids, should be given due consideration.

\section{ACKNOWLEDGMENTS}

This review was initiated within the framework of a project funded by the European Food Safety Agency (CFP/EFSA/ AHAW/2007/02) in order to review the literature of African swine fever. We are grateful to Dr. William Oliver, Chair of the IUCN Pigs, Peccaries, and Hippos Specialist Group, for allowing us to use IUCN maps as a template for those prepared for this review. We are grateful to the Wellcome Trust Foundation for funding some of the results reported in this article in Senegal, Democratic Republic of Congo, and Madagascar.

\section{REFERENCES}

Alcaraz C, Rodriguez F, Oviedo JM, Eiras A, De Diego M, Alonso C, et al. (1995) Highly specific confirmatory Western blot test for African swine fever virus antibody detection using the recombinant virus protein p54. Journal of Virological Methods 52:111-119

Anderson EC, Hutchings GH, Mukarati N, Wilkinson PJ (1998) African swine fever virus infection of the bushpig (Potamochoerus porcus) and its significance in the epidemiology of the disease. Veterinary Microbiology 62:1-15

Arias ML, Sanchez-Vizcaino JM (2002) African swine fever. In: Trends in Emerging Viral Infections of Swine, Morilla A, Yoon KJ, Zimmermann JF (editors), IA: Iowa State University Press, pp 119-139

Arnot LF, Du Toit JT, Bastos ADS (2009) Molecular monitoring of African swine fever virus using surveys targeted at adult
Ornithodoros ticks: a re-evaluation of Mkuze Game Reserve, South Africa. Onderstepoort Journal of Veterinary Research (in press)

Bastos ADS, Penrith ML, Cruciere C, Edrich J, Hutchings G, Roger F, et al. (2003) Genotyping field strains of African swine fever virus by partial p72 gene characterization. Archives of Virology 148:693-706

Bastos ADS, Arnot LF, Jacquier MD, Maree S (2009) A hostspecies informative internal control for molecular assessment of African swine fever virus infection rates in the African sylvatic cycle Ornithodoros vector. Medical and Veterinary Entomology. doi:10.1111/j.1365-2915.2009.00828.x

Bech-Nielsen S, Fernandez J, Martinez-Pereda F, Espinosa J, Perez Bonilla Q, Sanchez-Vizcaino JM (1995) A case study of an outbreak of African swine fever in Spain. British Veterinary Journal 151:203-214

Beltran Alcrudo D, Lubroth J, Depner K, De La Rocque S (2008) African swine fever in the Caucasus. Empress Watch 1-8, $\mathrm{ftp} / / / \mathrm{ftp}$.fao.org/docrep/fao/011/aj214e/aj214e00.pdf

Boshoff CI, Bastos ADS, Gerber LJ, Vosloo W (2007) Genetic characterisation of African swine fever viruses from outbreaks in southern Africa (1973-1999). Veterinary Microbiology 121:45-55

Costard S, Wieland B, De Glainville W, Jori F, Rowlands R, Vosloo W, et al. (2009) African swine fever: how can global spread be prevented? Philosophical Transactions of the Royal Society of London. Series B: Biological Sciences (London) 364:2683-2696

Cumming DHM (2005) Superorder Cetartiodactyla, order Suiformes. In: The Mammals of the Southern African Subregion, Skinner J, Chimimba CT (editors), Cambridge, UK: Cambridge University Press, pp 547-555

d'Huart J (1993) The Forest Hog (Hylochoerus meinertzhageni). In: Pigs, Peccaries, and Hippos, Oliver W (editor), Gland, Switzerland: IUCN, pp 84-92

d'Huart JP, Grubb P (2001) Distribution of the common warthog (Phacochoerus africanus) and the desert warthog (Phacochoerus aethiopicus) in the Horn of Africa. African Journal of Zoology 39:29-45

De Tray DE (1959) African swine fever in warthogs (Phacochoerus aethiopicus). Journal of the American Veterinary Medical Association 130:537-540

De Tray DE (1963) African swine fever. Advances in Veterinary Science and Comparative Medicine 19:299-333

Estes RD (2008) The Safari Companion. A Guide to Watching African Mammals, Johannesburg, South Africa: Russell Friedman Books, pp 1-458

Hamblin C, Anderson EC, Jago M, Mlengeya T, Hirji K (1990) Antibodies to some pathogenic agents in free-living wild species in Tanzania. Epidemiology and Infection 105:585-594

Haresnape JM, Lungu SA, Mamu FD (1985) A four year survey of African swine fever in Malawi. Journal of Hygiene (London) 95:309-323

Haresnape JM, Mamu FD (1986) The distribution of ticks of the Ornithodoros moubata complex (Ixodoidea: Argasidae) in Malawi, and its relation to African swine fever epizootiology. Journal of Hygiene (London) 96:535-544

Haresnape JM, Wilkinson PJ, Mellor PS (1988) Isolation of African swine fever virus from ticks of the Ornithodoros moubata complex (Ixodoidea: Argasidae) collected within the African swine fever enzootic area of Malawi. Epidemiology and Infection 101:173-185 
Heuschele WP, Coggins L (1969) Epizootiology of African swine fever virus in warthogs. Bulletin of Epizootic Diseases of Africa 17:179-183

Horak IG, Biggs HC, Hanssen TS, Hanssen RE (1983) The prevalence of helminth and arthropod parasites of warthog, Phacochoerus aethiopicus, in south West Africa/Namibia. Onderstepoort Journal of Veterinary Research 50:145-148

Jori F, Vial L, Ravaonamanana J, Le Glaunec G, Etter E, Akakpo J, et al. (2007) The role of wild hosts (wild pigs and ticks) in the epidemiology of African swine fever in West Africa and Madagascar. In: Proceedings of the 12th International Conference of the Association of Institutions of Tropical Veterinary Medicine, Montpellier, France, Camus E, Cardinale E, Dalibard C, Martinez D, Renard JF, Roger F (editors), pp 8-22

Kingdon J (2003) The Kingdon Field Guide to African Mammals, London: A\&C Blackwell Publishers

Kleiboeker SB, Scoles GA (2001) Pathogenesis of African swine fever virus in Ornithodoros ticks. Animal Health Research Reviews 2:121-128

Laddomada A, Patta C, Oggiano A, Caccia A, Ruiu A, Cossu P, et al. (1994) Epidemiology of classical swine fever in Sardinia: a serological survey of wild boar and comparison with African swine fever. Veterinary Record 134:183-187

Louza AC, Boinas FS, Caiado JM, Vogario JD, Hess WR (1989) Rôle des vecteurs et des réservoirs animaux dans la persistence de la Peste porcine africaine au Portugal. Epidémiologie et Santé Animale 15:89-102

Lubisi BA, Bastos ADS, Dwarka RM, Vosloo W (2005) Molecular epidemiology of African swine fever in East Africa. Archives of Virology 150:2439-2452

Luther NJ, Majiyagbe KA, Shamaki D, Lombin LH, Antiagbong JF, Bitrus Y, et al. (2007) Detection of African swine fever virus genomic DNA in a Nigerian Red River hog (Potamochoerus porcus). Veterinary Record 160:58-59

Mannelli A, Sotgia S, Patta C, Oggiano A, Carboni A, Cossu P, Laddomada A (1998) Temporal and spatial patterns of African swine fever in Sardinia. Preventive Veterinary Medicine 35:297306

Mansveld PR (1963) The incidence and control of African swine fever in the Republic of South Africa. Bulletin de l'Office International des Epizooties 60:889-894

Mauget R (1991) Reproductive biology of the wild Suidae. In: Biology of Suidae, Barret RH, Spitz F (editors), France: IRGM, pp 49-64

Mayer JM, Brisbin IL (1997) Distinguishing feral hogs from introduced wild boar and their hybrids: a review of past and present efforts. Proceedings of the Feral Pig Symposium, Orlando, FL. Available: http://texnat.tamu.edu/symposia/feral/ feral-7.htm [accessed February 1, 2009]

McVicar JW, Mebus CA, Becker HN, Belden RC, Gibbs EP (1981) Induced African swine fever in feral pigs. Journal of the American Veterinary Medical Association 179:441-446

Montgomery RE (1921) On a form of swine fever occurring in British East Africa (Kenya Colony). Journal of Comparative Pathology 34:243-262

Oliver WLB, Brisbin L, Takahashi S (1993) The Eurasian wild pig. In: Pigs, Peccaries and Hippos Status Survey and Action Plan, Oliver WLB (editor), Gland, Switzerland: IUCN, pp 107-191

Oura CA, Powell PP, Anderson E, Parkhouse RM (1998) The pathogenesis of African swine fever in the resistant bushpig. Journal of General Virology 79:1439-1443
Penrith ML, Thomson GR, Bastos ADS (2004a) African swine fever. In: Infectious Diseases of Livestock with Special Reference to Southern Africa, Coetzer JAW, Tustin RC (editors), Cape Town, South Africa: Oxford University Press, pp 1088-1119

Penrith ML, Thomson GR, Bastos AD, Phiri OC, Lubisi BA, Du Plessis EC, et al. (2004b) An investigation into natural resistance to African swine fever in domestic pigs from an endemic area in southern Africa. Revue Scientifique et Technique 23:965-977

Penrith ML, Lopes Pereira C, Lopes da Silva MM, Quembo C, Nhamusso A, Banze J (2007) African swine fever in Mozambique: review, risk factors and considerations for control. Onderstepoort Journal of Veterinary Research 74:149-160

Perez J, Fernandez AI, Sierra MA, Herraez P, de las Mulas JM (1998) Serological and immunohistochemical study of African swine fever in wild boar in Spain. Veterinary Record 143:136139

Perez-Filgueira DM, Gonzalez-Camacho F, Gallardo C, ResinoTalavan P, Blanco E, Gomez-Casado E, et al. (2006) Optimization and validation of recombinant serological tests for African swine fever diagnosis based on detection of the p30 protein produced in Trichoplusia ni larvae. Journal of Clinical Microbiology 44:3114-3121

Pierce MA (1974) Distribution and ecology of Ornithodoros moubata porcinus Walton (Acarina) in animal burrows. Bulletin of Entomological Research 64:605-609

Pini A, Hurter LR (1975) African swine fever: an epizootiological review with special reference to the South African situation. Journal of South African Veterinary Medical Association 46:227232

Plowright W (1977) Vector transmission of African swine fever virus. In: Commission of the European Communities Seminar on Hog Cholera/Classical Swine Fever and African Swine Fever. Report EUR 5903 EN, pp 575-587

Plowright W (1981) African swine fever. In: Infectious Diseases of Wild Mammals, Davis JW, Karstad LH, Trainer DO (editors), Ames, IA: Iowa State University Press, pp 178-190

Plowright W, Parker J, Pierce MA (1969) African swine fever virus in ticks (Ornithodoros moubata, Murray) from Tanzania. Nature 221:1071-1073

Plowright W, Perry CT, Pierce MA, Parker J (1970) Experimental infection of the argasid tick, Ornithodoros moubata porcinus, with African swine fever virus. Archiv für die gesamte Virusforschung 31:33-50

Plowright W, Thomson GR, Neser JA (1994) African swine fever. In: Infectious Diseases of Livestock with Special Reference to Southern Africa, Coetzer JAW, Thomson GR, Tustin RC (editors), Cape Town, South Africa: Oxford University Press, pp 567-599

Roger F, Ratovonjato J, Vola P, Uilenber G (2001) Ornithodoros porcinus ticks, bushpigs, and African swine fever in Madagascar. Experimental and Applied Acarology 25:263-269

Rowlands RJ, Michaud V, Heath L, Hutchings G, Oura C, Vosloo W, et al. (2008) African swine fever virus isolate, Georgia, 2007. Emerging Infectious Diseases 14:1870-1874

Seydack AHW (1990) The ecology of the bushpig (Potamochoerus porcus Linn. 1758) in the Cape Province, South Africa. PhD thesis, University of Stellenbosch, Stellenbosch, South Africa

Siméon-Negrin RE, Frias-Lepoureau MT (2002) Eradication of African swine fever in Cuba (1971 and 1980). In: Trends in Emerging Viral Infections of Swine, Morilla A, Yoon KJ, Zimmermann JF (editors), Iowa State University Press, pp 125-131 
Taylor WP, Best JR, Colquhoun IR (1977) Absence of African swine fever from Nigerian warthogs. Bulletin of Animal Health Production in Africa 25:196-203

Thomson GR (1985) The epidemiology of African swine fever: the role of free-living hosts in Africa. Onderstepoort Journal of Veterinary Research 52:201-209

Thomson GR, Gainaru MD, Van Dellen AF (1980) Experimental infection of warthog (Phacochoerus aethiopicus) with African swine fever virus. Onderstepoort Journal of Veterinary Research 46:149-154

Thomson G, Gainaru MD, Lewis A, Biggs H, Nevill E, van der Pypekamp H, et al. (1983) The relationship between African swine fever virus, the warthog and Ornithodoros species in southern Africa. In: African Swine Fever, Wilkinson PJ (editor), Commission of the European Communities. Report EUR 2466 EN, pp 85-100

Tulman ER, Delhon GA, Ku BK, Rock DL (2009) African swine fever virus. Current Topics in Microbiology and Immunology 328:43-87

Vercammen P, Seydack AHW, Oliver WLB (1993) The bush pigs (Potamochoerus porcus and P. larvatus. In: Pigs, Peccaries and Hippos Status Survey and Action Plan, Oliver WLB (editor), Gland Switzerland: IUCN

Vial L, Diatta G, Tall A, Ba el H, Bouganali H, Durand P, et al. (2006) Incidence of tick-borne relapsing fever in West Africa: longitudinal study. Lancet 368(9529):37-43
Vial L, Wieland B, Jori F, Etter E, Dixon L, Roger F (2007) African swine fever virus DNA in soft ticks, Senegal. Emerging Infectious Diseases 13:1928-1931

Viñuela E (1985) African swine fever virus. Current Topics in Microbiology and Immunology 116:151-170

Walton GA (1962) The Ornithodorus moubata superspecies problem in relation to human relapsing fever epidemiology. Symposia of the Zoological Society of London 6:83-156

Walton GA (1979) A taxonomic review of the Ornithodoros moubata (Murray) 1877 (Sensu Walton, 1962) species group in Africa. Recent Advances in Acarology 2:491-500

White LJT (1994) Biomass of rain forest mammals in the Lopé Reserve, Gabon. The Journal of Animal Ecology 63:499-512

Wilkinson PJ (1984) The persistence of African swine fever in Africa and the Mediterranean. Preventive Veterinary Medicine 2:71-82

Wilkinson PJ (1988) The distribution of African swine fever virus isolated from Ornithodoros moubata in Zambia. Epidemiology and Infection 101:547-564

Wilkinson PJ (1989) African swine fever virus. In: Virus Infections of Vetebrates, Vol. 2: Virus Infections of Porcines, Penjaert MB (editor), Amsterdam: Elsevier, pp 17-35 